\title{
IJTIHÂD PERSPEKTIF MUHAMMAD IBN 'ABD AL-WAHHAB
}

\author{
M. Bashri Asy'ari \\ (Dosen Tetap pada Jurusan Syari'ah STAIN Pamekasan dan Alumni S2 Islamic \\ International University Islamabad Pakistan)
}

\begin{abstract}
Abstrak:
Realitas mernunjukkan bahwa persoalan umat terus berkembang seiring dengan kemajuan zaman dan selalu membutuhkan solusi hukum Islâm. Karenanya, ijtihâd sangat dibutuhkan untuk menjawabnya sehingga hukum Islâm diharapkan berkembang dan mencapai kesempurnaan aktualisasinya. Alur berfikir inilah yang mendorong Ibn 'Abd al-Wahhab melakukan gerakan reformasi melalui semangat berijtihâd di kalangan kaum Muslim dan mencela sikap bermadzhab. Untuk mendorong ke arah tersebut, ia menunjukkan sikap reformisnya berupa ketidaksetujuannya atas pemberlakuan syarat-syarat yang ketat dalam ber-ijtihâd, sebagaimana yang ditetapkan oleh para ulamâ' terdahulu, yang, menurutnya, justru akan memunculkan wacana penutupan pintu ijtihâd dan keharusan ber-taqlîd.
\end{abstract}

Kata kunci:

ijtihâd, taqlîd, hukum Islâm, dan mujtahid,

\section{Pendahuluan}

Di antara pendidikan yang dikembangkan Rasûlullâh saw. kepada para sahabatnya adalah melatih mereka memfungsikan daya nalarnya untuk ber-ijtihâd dalam persoalan yang tak ada nash-nya dalam al-Qur'ân. Kasus shalat 'ashr pada perang Banî Quraydhah, dialog antara beliau dan Muâdz ibn Jabal ketika diutus menjadi Gubernur di Yaman, konsultasi beliau untuk menangani persoalan tawanan perang Badar, serta apakah pasukan Muslim harus keluar dari Kota Madînah atau tidak pada perang Uhûd, merupakan bukti riil dari hal tersebut. Oleh karenanya para sahabat dan tâbi'în memandang tak ada persoalan untuk ber-ijtihâd bagi mereka yang 
mampu untuk ber-ijtihâd, dan menganggap perbedaan hasil ijtihâd mereka sebagai hal yang biasa dan diperbolehkan oleh Allâh dan Rasûl-Nya.

Pada awal abad keempat hijriyah, memang terjadi perubahan luar biasa di mana terdapat kecenderungan untuk menutup pintu ijtihâd dan mencukupkan diri bermadzhab pada salah satu madzhab yang empat, yaitu Hanafî, Mâlikî, Syâfi'î dan Hanbalî. Kemudian terjadi perkembangan baru lagi dengan munculnya kelompok yang mewajibkan ijtihâd dan melarang taqlîd serta mengharamkan pola bermadzhab. Kelompok ini dipelori oleh Ibn Hazm, seorang pengikut madzhab Hanbalî. Dengan demikian, terdapat dua kelompok yang memiliki pandangan berbeda dan bahkan berseberangan dalam menyikap persoalan ijtihâd dan taqlîd. Keduanya sama-sama ekstrem dan melahirkan perilaku yang ekstrem pula berupa sikap saling menyalahkan di antara mereka.

Dari kelompok yang berpendapat bahwa pintu ijtihâd terbuka, muncul gerakan mempermudah ijtihâd dan menyederhanakannya dengan mengusung slogan "kembali kepada al-Qur'ân dan alSunnah". Pendirian ini memberikan kesempatan kepada siapa pun untuk ber-ijtihâd walaupun tidak memiliki keahlian dan kapasitas untuk itu. Akibatnya, lahirlah produk-produk ijtihâd yang kontroversial dan menggiring teks-teks tersebut pada hal-hal yang tak menjadi jangkauannya. Sebaliknya, kelompok yang berpendirian bahwa pintu ijtihâd telah tertutup melahirkan sikap fanatisme yang berlebihan kepada orang yang tak lepas dari kesalahan, taqlîd buta, dan tidak memfungsikan daya nalarnya untuk berinteraksi secara langsung dengan teks-teks al-Qur'ân dan al-Hadîts, padahal mereka memiliki kapasitas untuk itu. Dari sini lahirnya beberapa kesalahan dalam mengkaji figh Islâm, yaitu sikap fanatisme yang hanya melihat kebenaran ada pada madzhabnya, dan sebaliknya benci kepada figh, menolak mengkaji al-Qur'ân dan al-Sunnah karena figh, dan sebaliknya menolak fiqh karena mencukupkan diri kepada al-Qur'ân dan al-Sunnah. ${ }^{1}$ Seharusnya antara pengkajian hukum langsung dari al-Qur'ân dan al-Sunnah dan pemanfaatan hasil ijtihâd ulamâ' terdahulu, tidak boleh dipisahkan satu sama lainnya, apalagi

1 'Abd Allâh Qâshîm al-Wasylî, al-Nahj al-Mubîn li Syarh al-Ushûl al-'Isyrîn (Jeddah: Dâr al-Mujtama',1990), hlm.168. 
diingkari. Pengingkaran seperti ini, menurut Said Hawwa, hanya bisa dilakukan oleh orang yang tidak mengerti sama sekali tentang kondisi riil dari penetapan hukum Islâm. ${ }^{2}$

Tidak semua orang boleh ber-ijtihâd sebagaimana juga tidak semua orang boleh ber-taqlîd, tetapi ada yang boleh berijtihâd dan boleh ber-taqlîd tergantung kepada kapasitas masing-masing. AlAmîdî menggolongkan manusia menjadi tiga tingkatan, yaitu: (1) Orang yang mencapai peringkat mujtahid, maka ia dibebanai untuk mengikuti ijtihâd yang dicapainya; (2) orang yang mengetahui sumber pendapat-pendapat dan rujukannya tetapi belum mencapai peringkat mujtahid, maka ia dibebanani untuk memilih pendapat dari para imam yang ia yakini benar dan puas dengan pendapat itu; dan (3) orang awam, maka baginya hendaknya mengikuti pendapat salah seorang dari para imam mujtahid. ${ }^{3}$ Bagi kelompok kedua seharusnya terus meningkatkan kapasitas keilmuannya sehingga diharapkan mampu meraih peringkat mujtahid, mengingat persoalan umat pada setiap masa berbeda dengan persoalan yang dihadapi oleh pendahulunya sehingga ijtihâd pun menjadi sebuah keniscayaan.

\section{Biografi Muhammad Ibn 'Abd al-Wahhab.}

Muhammad Ibn Abd al-Wahhab dilahirkan di 'Uyaynah, sebelah Barat Daya Ibu Kota Riyadl pada 115 H atau 1703 M. Ia lahir dan dibesarkan dalam lingkungan keluarga yang berilmu dan taat beragama. Ayahnya menjabat sebagai jaksa di 'Uyaynah dan Huraymala'. Sebagai salah seorang ulamâ' Hanabilah, ia tercatat sebagai pengajar tetap bidang fiqh, tafsîr dan hadîts di Masjid 'Uyaynah. Pendidikan pertama Ibn 'Abd al-Wahhab sendiri diterima dari ayahnya. Darinya, ia belajar fiqh madzhab Hanbalî. Selanjutnya, saat menuaikan ibadah haji dan menetap di Madinah, ia menimba ilmu dari Syaykh Abd Allâh ibn Ibrâhîm Ali Sayf dan Syaykh Hayâh al-Sanadi. Diceritakan bahwa pada suatu hari Ibn 'Abd al-Wahhab menyaksikan orang-orang memohon pertolongan kepada Rasûlullâh saw. sambil mengusap-ngusap batu nisannya. Kejadian itu kemudian dilaporkan kepada gurunya Syaykh al-Sanadi. Ia berkomentar,

2 Ibid.

3Sayf al-Dîn al-Amîdî, al-Ihkâm fî Ushûl al-Ahkâm, Vol. IV (Kairo: Muassasah al-Nur, $1384 \mathrm{H})$, hlm. 230 
"sesungguhnya apa yang mereka kerjakan adalah kebatilan". Menurut salah satu riwayat, kepribadian gurunya inilah yang mempengaruhi perjalanan hidup Ibn 'Abd al-Wahhab.

Kemudian ia melanjutkan perjalanannya ke Bashrah. Di sana ia belajar nahw, bahasa dan figh kepada Syaykh Muhammad alMajmû'î. Di Bashrah inilah, ia juga mulai melakukan dakwah pemurnian tauhid dengan mengatakan bahwa kecintaan kepada para wali dan orang shaleh dilakukan dengan cara mengikuti petunjuk dan warisan intelektual mereka, bukan dengan cara menjadikan mereka tuhan-tuhan yang disembah selain Allâh. Sejak saat itu, ia mendapat kecaman dari berbagai pihak dan dipersempit ruang geraknya. Akibatnya, ia terpaksa meninggalkan Basrah dan kembali ke Najed melewati Ihsa' dan menyempatkan diri berguru kepada Syaykh Abd Allâh Ibn Muhammad Ibn Abd al-Lathîf al-Syâfi'î di bidang ilmu Tafsîr dan Hadîts. Kemudian, ia kembali menuju Huraymala', tempat tinggal ayahandanya yang baru, dan memulai dakwahnya kembali yang difokuskan pada pemberantasan bid'ah, syirik dan khurafat. Tetapi ayahnya melarang aktifitasnya karena khawatir amukan massa penentangnya.

Akhirnya ia hijrah ke 'Uyaynah, tempat kelahirannya, dan ternyata mendapat dukungan dari Amir Utsmân Ibn Hamad Ibn Muammar, penguasa Uyaynah saat itu. Ada tiga hal yang dilakukannya selama keberadaannya di sana, yaitu membongkar kubah yang dibangun di atas kuburan Zaid Ibn al-Khaththâb, memotong pohon yang dijadikan tempat minta barakah, dan merajam seorang wanita yang mengaku berzina di hadapannya dan meminta untuk dilakukan had kepadanya. Pelaksanaan sanksi ini dilakukan oleh Amir 'Uyaynah sendiri sehingga membuat geger masayarakat di sana dan membuat penguasa Ihsa' marah serta meminta amir Uyainah memilih dua alternatif, yaitu gaji tahunannya dicopot atau mengusir Muhammad Ibn 'Abd al-Wahhab. Amir itu memilih alternatif kedua dengan menyuruh Ibn 'Abd al-Wahhab meninggalkan Uyainah dan hijrah ke Dar'iyah. Di sana ia mendapat dukungan kuat dari Muhammad Ibn Saud (pendiri Kerajaan Arab Saudi sekarang), dan berhasil mengembangkan gerakan dakwahnya, yaitu memberantas bid'ah dan khurafat. Di samping itu, ia bersama Ibn Saud membangun kerajaan Arab Saudi yang membawa panji 
gerakan reformasinya yang kemudian dikenal dengan gerakan Wahhabî.

Ia meninggalkan beberapa karya tulis berupa surat-surat yang dikirimkan kepada penguasa dan ulamâ' di berbagai daerah untuk menjelaskan pokok-pokok pikiran dan dakwahnya. Di samping itu, terdapat pula beberapa buku yang sebagian besar mengulas tentang tauhid, di antaranya, yaitu al-Tawhîd, Kasyf al-Syubuhât, Kitâb Tafsîr alQur'ân, Kitâb Ushûl al-Dîn, Mukhtashar al-Hâdî al-Nabawî̀, Tafsîr Sûrah al-Fâtihah, Tafsîr Kalimat al-Tawhîd, Ahâdîts al-Fitan, al-Amr bi al-Ma'rûf wa al-Nahy 'an al-Munkar, dan lain-lainnya. ${ }^{4}$

\section{Ijtihâd dalam Perspektif Ibn 'Abd al-Wahhab}

Menurut para ulamâ' ushûl dan fuqahâ', ijtihâd dimaknai sebagai upaya maksimal dari seorang fâqih untuk mengelurkan hukum dari dalil-dailnya yang terperinci. Ini berarti bahwa kerja ijtihâd dinyatakan selesai dengan berhasilnya penemuan hukum dari dalil-dalil yang terperinci. ${ }^{5}$ Berbeda dengan pengertian tersebut, Ibn 'Abd al-Wahhab berpendapat bahwa ijtihâd berarti mengembalikan sesuatu yang diperselisihkan kepada al-Qur'ân dan al-Sunnah karena pada keduanya terdapat penyelesaiannya. ${ }^{6}$ Ini berarti bahwa yang harus dilakukan mujtahid pertama kali adalah mencari teks-teks yang terkait dengan satu masalah sebelum mengeluarkan hukum. ${ }^{7}$

Seorang mujtahid bisa jadi memutuskan suatu hukum berdasarkan ijtihâd-nya karena tidak ada nash atau belum sampai kepadanya dalil syar' $\hat{\imath}$, maka jika di kemudian hari terdapat nash yang menggugurkan ijtihâd-nya, maka nash tersebut harus didahulukan. Begitu juga, apabila ijtihâd seorang mujtahid bertentangan dengan nash, maka nash itu dikedapankan. Dengan demikian, ijtihâd dalam pengertian tersebut tetap terbuka bagi siapa pun yang memiliki

${ }^{4}$ Muhammad Ibn 'Abd Allâh Ibn Sulaymân al-Salman, Dakwat al-Syaykh Muhammad Ibn 'Abd al-Wahhab wa Atsaruhâ fí al-'Alam (Riyadl: Dâr al-Mathbû'ah, 1988), hlm.25-31 5Dawûd al-Mûsâwî, Asyadd al-Jihâd fî Ibthâli Da'wat al-Ijtihâd (Turki: Isik Kitabev, 1980), hlm.18

${ }^{6}$ Amînah Muhammad Nashr, Al-Syaykh Muhammad Ibn 'Abd al-Wahhab wa Manhajuhu fî Mabâhits al-'Aqîdah (Beirut: Dâr al-Syuruq, 1983), hlm.71.

7 Ibn 'Abd al-Wahhab secara tegas menyatakan bahwa ia tidak mengajak kepada siapa pun kecuali kepada Allâh dan Rasul-Nya. Ini berarti Ibn 'Abd al-Wahhab bebas madzhab. Lihat Husayn Ibnu Ghannam, Târîkh al-Najd (Kairo: Mathba'ah al-Madanî, 1961), hlm.495 
kapasitas untuk melakukannya pada sepanjang masa. Baginya mujtahid mana pun yang ijtihâd-nya bertentangan dengan al-Qur'ân dan al-Sunnah harus ditolak. Hal ini didasarkan pada argumentasi bahwa jika Allâh swt. mengutus Muhammad saw. dengan petunjuk dan agama yang benar serta menyuruh umatnya untuk mengikutinya dan meninggalkan apa yang bertentangan dengannya, maka ulamâ' yang menentangnya harus ditegur dan ditolak pendapatnya. ${ }^{8}$

Untuk mendorong umat Muslim, yang kapasitas tertentu, melakukan ijtihâd, Ibn 'Abd al-Wahhab memberikan tanggapannya atas syarat-syarat bagi mujtahid yang ditetapkan oleh para ulamâ terdahulu. Sebagaimana dinyatakan oleh para ulamâ, bahwa syaratsyarat mujtahîd, yang bersifat umum, adalah Islâm, baligh dan berakal sehat. Sedangkan yang bersifat primer, ia harus menguasai terhadap sumber hukum Islâm, yaitu al-Qur'ân, al-Sunnah dan ilmu-ilmu yang terkait dengan keduanya, ijmấ', serta menguasai bahasa Arab dengan seluruh cabang-cabangnya. Tidak hanya itu, seorang mujtahid harus memenuhi syarat-syarat sekunder, seperti menguasai maqâshid alsyarî'ah, mengetahui ruang ikhtilâf, memiliki ilmu manthiq, dan memiliki moralitas yang baik, misalnya jujur dan warấ. ${ }^{\prime}$

Syarat-syarat mujtahid yang ketat seperti itu, menurut Ibn 'Abd al-Wahhab terlalu sulit untuk dipenuhi. Karenanya, ia menyindir pemberlakuan syarat-syarat yang ketat tersebut sebagai tindakan mengekor hawa nafsu. Dalam kaitan ini, ia berkata, "sunnah (kebiasaan) yang diletakkan syaitan adalah bahwa al-Qur'ân dan al-Sunnah tidak bisa dipahami kecuali oleh mujthaid muthlak yang memiliki sifat-sifat ini, di mana mereka bisa jadi tidak dimiliki secara utuh oleh 'Umar dan Abû Bakar. Karenanya, jika seseorang tidak memiliki sifat-sifat demikian, maka ia wajib berpaling dari keduanya (al-Qur'ân dan al-Sunnah) sehingga tidak mendatangkan masalah. Dan barang siapa yang mencari petunjuk langsung dari keduanya, maka ia seorang zindiq atau gila karena kesulitannya. Maha Suci Allâh dan segala puji bagi-Nya.10 Pernyataan Ibn 'Abd al-Wahhab yang memahami betul metode istinbât hukum Islâm dalam madzhab Hanbalî, tidak dapat diartikan menolak keseluruhan syarat-syarat

${ }^{8}$ Nashr, al-Syaykh, hlm. 73

${ }^{9}$ Nadîyah Syarîf al-Umarî, al-Ijtihâd fî al-Islâm (Beirut: Muassasah al-Risâlah, 1985) hlm. 59

${ }^{10}$ Muhammad Ibn 'Abd al-Wahhab, Majmu'ah al-Tawhîd (Riyadl: al-Maktabah alHadîtsah, t.th.) hlm. 276. 
mujtahid tersebut, tetapi lebih mencerminkan sifat reformisnya yang tidak setuju atas pemberlakuan syarat-syarat tersebut secara ketat sehingga kemudian memunculkan wacana penutupan pintu ijtihâd dan keharusan ber-taqlîd. Ibn 'Abd al-Wahhab, seperti pendahulunya Ibn Taimiyah dan Ibn al-Qayyim, membolehkan siapa pun untuk berijtihâd dalam satu masalah yang dikuasainya, karena ijtihâd bisa bersifat parsial. ${ }^{11}$

Berkenaan dengan ruang lingkup ijtihâd, Ibn 'Abd al-Wahhab tidak memiliki pendapat yang berbeda dengan para ulamâ' sebelumnya, yaitu bahwa ijtihâd hanya dapat diberlakukan pada persoalan furî̀'îyah dan pada teks-teks zhannîyat al-dalâlâh. Dengan demikian tak ada ruang ijtihâd pada nash qath'îyat al-tsubît dan qath'îyat al-dalâlah serta ijma' ulamâ'. Dalam kaitan ini, ia berseru, "Aku mengajak orang yang berbeda denganku, untuk kembali pada Kitâb Allâh atau Sunnah Rasûl-Nya, atau ijmấ' para ulamâ' '.12

\section{Pola Hubungan Antar Mujtahid}

Dalam suatu masa bisa jadi terdapat beberapa mujtahid yang memiliki pandangan berbeda dalam berbagai persoalan. Contohnya adalah Umar ibn al-Khattâb, Ali ibn Abî Thâlib, Ibnu Abbâs, Ibnu Umar, Mu'âdz bin Jabal dan sahabat-sabhabat lainnya adalah para mujtahid yang berada dalam satu masa dan menghasilkan ijtihâd yang terkadang berseberangan. Namun demikian, mereka saling memamahi dan tidak memaksakan pendapatnya dikarenakan masing-masing mereka menyadari akan jati dirinya. Ibnu Abbâs, misalnya, sering berbeda pendapat dengan Ibnu Mas'ûd, dan bahkan Ibnu Umar menolak ijtihâd bapaknya sendiri. ${ }^{13}$

Demikian halnya dengan para imâm madzhab, mereka saling menghormati dan saling tukar-menukar ilmu pengetahuan serta tidak memaksakan pendapatnya kepada siapa pun, termasuk muridnya sendiri. Imâm Syâfi'î, misalnya, berkata kepada Imâm Ahmad: "Wahai Abû Abdillah, Engkau lebih pintar dari aku tentang_hadîts, jika ada hadîts shahîh beritahukan aku sehinga aku pergi mencarinya baik perawi itu

\footnotetext{
${ }^{11}$ al-Wasylî, al-Nahj al-Mubîn, hlm. 175. Lihat juga Ibn Taymiyah, al-Fatâwâa al-Kubrâ, Vol. 20 (Maroko: Maktabah al-Ma'ârif, t.th.), hlm.204.

12 Ibid.,74

13 Al-Syawkânî, Irsyâd al-Fuĥûl (Kairo: Thab'ah Muhammad 'Alî Shubayh, t.th.), hlm. 249.
} 
orang Syam, Kufah atau pun Bashrah". ${ }^{14}$ Imâm Abû Hanîfah berkata kepada Abû Yûsûf: "Tidak boleh seseorang mengikuti pendapatku sampai ia tahu dari mana aku menyandarkannya". ${ }^{15}$ Dari perkataan mereka tampak jelas bahwa setiap mujtahid memiliki kebebasan memilih pendapatnya sendiri. Apabila terdapat kesamaan hasil ijtihâd atau mengambil hasil ijtihâd mujtahid lainnya, mereka tidak menirunya, tetapi karena menerima dalil yang dijadikan sandarannya. Walhasil, tradisi keilmuan yang berlaku pada saat itu adalah melihat keunggulan argumentasi sang mujtahid bukan pribadinya.

Tradisi keilmuan seperti ini terus berkembang hingga munculnya pembatasan dan keharusan bermadzhab. Pola bermadzhab tersebut juga dijadikan sebagai alat pembelenggu pemikiran dan tolok ukur loyalitas murid kepada gurunya, bahkan yang lebih tragis lagi memosisikan pendapat madzhab sebagai agama yang tak boleh boleh ditolak dan digugat. ${ }^{16}$ Sebenarnya pada abad X M muncul beberapa ulamâ' yang brilliant, seperti Syaykh Khalîl alMâlikî, al-Subukî, dan al-Suyûthî yang memiliki kapasitas untuk berijtihâd, tetapi mereka tidak memanfaatkannya. Alih-alih, mereka hanya mensyarah atau meringkas pendapat para imâm madzhab, sehingga malah sulit dipahami.

Kondisi itulah yang kemudian ditentang oleh Ibn 'Abd alWahhab. Ia berusaha mencairkan kembali kejumudan madzhab dengan mengajak kembali pada semangat ijtihâd, sebagaimana yang terjadi pada periode awal Islâm, dengan cara meneliti dalil sebelum dijadikan dalil penetapan sebuah hukum oleh seseorang. Dengan demikian, kebenaran ijtihâd bukan karena tokohnya, tetapi sebaliknya tokoh dikenal karena kebenaran yang ada padanya. Selanjutnya, ia berkata: "Jika sebuah nash al-Qur'ân atau al-Sunnah nyata kebenarannya, tidak mansûkh tidak ditakhshîsh, dan tidak ada nash lebih kuat yang menentangnya, kami mengambilnya dan kami tinggalkan madzhab. Bagi kami, Imâm Ibn al-Qayyim dan Ibn Taymiyahmerupakan imâm ahl alsunnah dan kitab-kitabnya merupakan kitab yang paling berharga, tetapi kami tidak bertaqlîd kepada keduanya dalam setiap persoalan, karena setiap

14 Ibd.,hlm.,261

15Ibid. hlm. 249.

${ }^{16}$ Muhammad Ibn 'Abd al-Wahhab, et.al., al-Durar al-Tsâniyah fí al-Ajwibat al-Najdîyah, Vol. 4 (Saudi Arabia: Dâr al-Ifta', 1965), hlm. 8 
perkataan seseorang bisa diambil dan ditolak kecuali sabda Nabi saw."17 Pernyataan ini betul-betul dibuktikan olehnya dengan mengeluarkan pendapat yang berbeda dari keduanya, Ibn Taimiyah dan Ibn alQayyim, dalam beberapa persoalan, seperti mengikuti pendapat empat madzhab dalam hal thalâq tiga dalam satu lafadz dalam satu majelis dan dalam masalah nadzar yang boleh dan wajib ditepati selama tidak ada unsur maksiat di dalamnya. ${ }^{18}$

\section{Penutup}

Pengaruh lingkungan keluarga, pengalaman pendidikan, dan perjalanan kehidupan sosio-politik tampak sangat berpengaruh dalam pembentukan pandangan dan kepribadian Ibn 'Abd alWahhab. Pendapatnya yang khas adalah bahwa sebuah dalil harus jelas diambil dari al-Qur'ân dan al-Sunnah, sedangkan nalar diposisikan sebagai pembenar nash, sebagai saksi, dan bukan sebagai penentu. Karenanya, produk ijtihâd atau pendapat yang mengabaikan nash shahîh harus ditolak, terutama yang berkaitan dengan persoalan aqîdah. Pendirian ini terus ditegakkan walaupun ia harus berhadapan dengan penguasa dan masyarakat yang menentangnya. Akhirnya apa pun kekurangan yang dimilikinya, yang pasti ia telah memberikan terobosan baru dengan mempermudah prasyarat mujtahid dan bahwa ijtihâd bisa bersifat parsial serta mampu membangkitkan semangat umat Islâm dari kelesuan ber-ijtihâd yang pengaruhnya menyebar di seluruh dunia Islâm. ${ }^{19}$ Wallâh a'lam bi al-Shawab.

\section{Daftar Pustaka}

Amîdî, Sayf al-Dîn al-. al-Ihkâm fî̀ Ushûl al-Ahkâm, Vol. IV. Kairo: Muassasah al-Nur, $1384 \mathrm{H}$.

Asad, Muhammad. Jalan Menuju Islam. Jakarta: Al-Maarif, t.th.

\footnotetext{
17 Nashr, al-Syaykh, hlm. 79

${ }^{18}$ Ghannam, Târîkh al-Najd, hlm. 495.

19 Berkaitan dengan hal ini, Muhammad Asad mengatakan bahwa semua gerakan

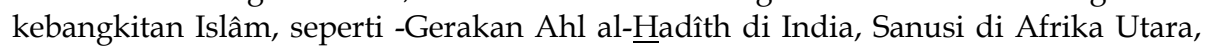
karya Jamal-Dîn al-Afghanî, dan dan pergerakan Muhammad 'Abduh di Mesir memperoleh dorongan kejiwaan Ibn 'Abd al-Wahhab pada abad XVIII M. Baca Muhammad Asad, Jalam Menuju Islam (Jakarta: Al-Maarif, t.th), hlm. 200-201.
} 
Ghannam, Husayn Ibnu. Târîkh al-Najd. Kairo: Mathba'ah al-Madanî, 1961.

Mûsâwî Dawûd al-., Asyadd al-Jihâd fî Ibthâli Da'wat al-Ijtihâd. Turki: Isik Kitabev, 1980.

Nashr, Amînah Muhammad. Al-Syaykh Muhammad Ibn 'Abd al-Wahhab wa Manhajuhu fî̀ Mabâhits al-'Aqîdah. Beirut: Dâr al-Syuruq, 1983.

Salman, Muhammad Ibn 'Abd Allâh Ibn Sulaymân al-. Dakwat alSyaykh Muhammad Ibn 'Abd al-Wahhab wa Atsaruhâ fî al-'Alam. Riyadl: Dâr al-Mathbû'ah, 1988.

Syawkânî, Al-. Irsyâd al-Fuhn̂ul (Kairo: Thab'ah Muhammad 'Alî Shubayh, t.th.

Taymiyah, Ibn. al-Fatâwâa al-Kubrâ, Vol. 20. Maroko: Maktabah alMa'ârif, t.th.

Umarî, Nadîyah Syarîf al-. al-Ijtihâd fî al-Islâm. Beirut: Muassasah alRisâlah, 1985.

Wahhab, Muhammad Ibn 'Abd al-, et.al., al-Durar al-Tsâniyah fî alAjwibat al-Najdîyah, Vol. 4. Saudi Arabia: Dâr al-Ifta', 1965.

------. Majmu'ah al-Tawhîd. Riyadl: al-Maktabah al-Hadîtsah, t.th.

Wasylî, 'Abd Allâh Qâshîm al-. al-Nahj al-Mubîn li Syarh al-Ushûl al'Isyrîn. Jeddah: Dâr al-Mujtama', 1990. 